\title{
Correlation between sperm DNA fragmentation index and semen parameters in 418 men seen at a fertility center
}

\author{
Láyonal Germán Acosta Campos ${ }^{1}$, Lissett Chiscul Requejo ${ }^{1}$, Carlos Antonio Rivas Miñano ${ }^{1}$, Jheny Díaz Orrego ${ }^{1}$, \\ Elmer Chávez Loyaga ${ }^{1}$, Luis Gonzales Cornejo ${ }^{1}$
}

${ }^{1}$ IN VITRO GESTAR, Assisted Reproduction Center. Chiclayo, Perú

\begin{abstract}
Objective: The aim of this study was to determine the correlation between semen parameters and sperm DNA fragmentation index (DFI) in 418 men who attended a fertility center.

Methods: This retrospective study includes 418 male patients seen at In Vitro Gestar, Chiclayo - Perú between October 2013 and March 2020. DFI was determined between normozoospermic patients (NORMO) and patients with one altered parameter (ALTERED). The patients were classified as oligozoospermic [Severe/Moderate oligozoospermia (OLIGO SM): $<5 \times 106$ sperm/mL and Mild oligozoospermia (OLIGO M): 5 to $<15 \times 106 \mathrm{sperm} / \mathrm{mL}$ ], asthenozoospermic [Severe asthenozoospermia (ASTHENO S): $<10 \%$ PM (progressive motility); Moderate asthenozoospermia (ASTHENO MO): 10 to $<20 \%$ PM; Mild asthenozoospermia (ASTHENO M): 20 to $<32 \% \mathrm{PM}$ )], teratozoospermic (TERATO) and oligoasthenoteratozoospermic (OAT). DFI was determined between these groups and NORMO. The data was analyzed using the SPSS 22.0 software for Windows.

Results: Normozoospermic patients presented lower significant levels of DFI compared with all groups. NORMO $(15.64 \pm 7.65)$ vs [ALTERED $(18.41 \pm 9.43, p=0.003)$; OLIGO SM $(26.38 \pm 12.94, p<0.005) ;$ ASTHENO S $(23.09 \pm 11.45$, $p<0.01)$; TERATO $(17.96 \pm 9.23, p<0.05)$ and OAT (22.05 $\pm 12.15, p=0.001)]$. We determined a significant negative correlation between DFI and progressive motility $(r=-0.162 p=0.001)$, and those with normal morphology $(r=-0.100 p=0.040)$. Likewise the DFI shows a significant positive correlation with age $(r=0.257 p=0.000)$.

Conclusions: Our study establishes that high DFI is accompanied by a significant impairment in all seminal parameters.
\end{abstract}

Keywords: Normozoospermia, Sperm DNA fragmentation, Infertile, progressive motility, oligoasthenoteratozoospermia

\section{INTRODUCTION}

Infertility is a disease of the reproductive system, defined by the failure to achieve a clinical pregnancy after 12 months or more of regular unprotected sexual intercourse (De Neubourg et al., 2012), and it affects approximately 8 to $12 \%$ of the word population (Kumar \& Singh, 2015). Male factor is implicated in almost $50 \%$ of cases and out of these; approximately $30-40 \%$ are idiopathic (Kadioglu $\&$ Ortac, 2017). These facts determine the importance of semen evaluation to verify fertility potential.

Conventional semen analysis or spermogram (sperm concentration, motility, morphology and vitality) is used for male fertility evaluation (WHO, 2010). However, it is estimated that approximately $10-15 \%$ of infertile men present normal semen analysis (Sharma et al., 2004;
Agarwal \& Allamaneni, 2005; Lewis et al., 2008). Likewise, the spermogram does not measure the fertilizing potential of spermatozoa and the complex changes that occur in the female reproductive tract before fertilization (Wang \& Swerdloff, 2014). Therefore, there may be other factors that affect male fertility and are not detected by the spermogram, for example: sperm membrane defects (Rajeev \& Reddy, 2004), environmental factors (Oliva et al., 2001), genetic factors (Kim et al., 2017) and sperm DNA fragmentation (Quintero et al., 2015; Ioannou et al., 2016).

Recent studies indicate that sperm DNA fragmentation test is a useful diagnostic tool in male infertility evaluation (Agarwal et al., 2016). Intact sperm DNA is necessary for correct transmission of genetic material to the next generation. High percentage of sperm DNA fragmentation index (DFI) is associated with reduced fertilization rates, early development embryo, embryo quality, pregnancy rates and higher rates of spontaneous miscarriage (Bungum et al., 2007; Lewis et al., 2013; Simon et al., 2014). Sperm DNA fragmentation can be caused by many factors, such as: apoptosis during sperm maturation in the seminiferous tubule epithelium (Gosálvez et al., 2015), defects in chromatin packaging and remodeling during the process of spermiogenesis (Sakkas et al., 2002; Shamsi et al., 2008), increase of reactive oxygen species (ROS) (Aitken \& De luliis, 2010; Alahmar, 2019) and decrease of seminal antioxidant (Shamsi et al., 2010). Obesity, stress, alcohol consumption, smoking, use of drugs, caffeine, diet and advanced age are also factors that increase DFI (Durairajanayagam, 2018).

The most common cause of DNA fragmentation in spermatozoa is reactive oxygen species (ROS) and oxidative stress (Agarwal et al., 2014; Majzoub et al., 2018; 2019). ROS are oxygen-derived free radicals, such as hydroxyl radicals $(\mathrm{OH})$, superoxide anion $\left(\mathrm{O}_{2}^{-}\right)$and hydrogen peroxide $\left(\mathrm{H}_{2} \mathrm{O}_{2}\right)$. Low levels of ROS are required for sperm capacitation, hyperactivation, acrosome reaction and spermatozoa-oocyte fusion. However, high concentration of seminal ROS is harmful in man (Moustafa et al., 2004; Aktan et al., 2013), and it alters semen parameters (Agarwal et al., 2014; Homa et al., 2015). ROS can also produce punctual mutations and polymorphisms, resulting in decreased semen quality (Spiropoulos et al., 2002).

Sperm chromatin structure assay (SCSA), terminal deoxynucleotidyl transferase (dUTP) nick-end labeling (TUNEL) assay, Comet assay, Acridine orange test and sperm chromatin dispersion (SCD) are some methods commonly used to identify sperm DNA fragmentation. SCD is characterized by its easy and fast application, as well as, low-cost.

It is based on the halo test, when sperm are treated with an acid solution prior to lysis buffer. The DNA dispersion halos found in sperms nuclei with fragmented DNA after the removal of nuclear proteins are either minimally present or not produced at all. (Fernandez et al., 2003; 
Fernandez et al., 2005). Studies have shown that SCD has high sensitivity to detect sperm with DNA fragmentation (Chohan et al., 2006; Zhang et al., 2010; Liffner et al., 2019). Different studies using SCD test have determined the reproductive capacity of the sperm and its correlation with seminal parameters and embryo quality after in vitro fertilization (Velez de La Calle et al., 2008; Feijó \& Esteves, 2013; Tandara et al., 2013; Acosta \& Dueñas, 2014; Acosta et al., 2015; Borges et al., 2019).

The purpose of our study was to determine the correlation between DFI and semen parameter in patients with normozoospermia, oligozoospermia, asthenozoospermia and teratozoospermia using the sperm chromatin dispersion (SCD) test.

\section{MATERIALS AND METHODS}

\section{Patients}

This descriptive retrospective study included 418 patients seen at the Andrology Laboratory of the Assisted Reproduction Center "In Vitro Gestar", Chiclayo - Perú, between October 2013 and March 2020. We excluded those patients with azoospermia, varicocele, cryptorchidism, antibiotic treatments, diabetes, a history of radiotherapy and chemotherapy, chronic diseases. In Vitro Gestar Committee approved this study.

\section{Sample collection and Semen Analysis}

The seminal samples were collected by masturbation into a sterile container after a sexual abstinence period of 3 - 7 days. The semen parameters were evaluated according to the WHO guidelines (WHO, 2010). Concentration and sperm motility were determined using a Makler chamber (Sefi-Medical Instruments, Haifa - Israel), and strict Kruger criteria was used for assessing sperm morphology (Papanicolaou staining). To find the normozoospermic patients (NORMO) and patients with an altered parameter (ALTERED), we followed the lower reference limit established by the WHO. The oligozoospermic patients were divided into groups: Severe/Moderate oligozoospermia (OLIGO SM) : $<5 \times 10^{6} \mathrm{sperm} / \mathrm{mL}$; mild oligozoospermia (OLIGO M): 5 to $<15 \times 10^{6} \mathrm{sperm} / \mathrm{mL}$. The asthenozoospermic patients were divided Based on their progressive motility (PM): Severe asthenozoospermia (ASTHENO S): <10\% PM; Moderate asthenozoospermia (ASTHENO MO): 10 to $<20 \%$ PM; Mild asthenozoospermia (ASTHENO M): 20 to $<32 \%$ PM. The teratozoospermic patients (TERATO) are those with $<4 \%$ normal morphology. The oligoasthenoteratozoospermic patients (OAT) are those with $<15 \times 10^{6} \mathrm{sperm} / \mathrm{m},<32 \% \mathrm{PM}$ and $<4 \%$ normal morphology.

Determination of DNA fragmentation Index (DFI)

We measured the DNA fragmentation Index of spermatozoa using the Sperm Chromatin Dispersion test (SCD) (Fernández et al., 2003; 2005) with the Halosperm Kit (Halotech DNA) with minor modifications. The normozoospermic patients' seminal samples were diluted in PBS (Phosphate-buffered saline) until reaching a concentration of 5 to $10 \times 10^{6} \mathrm{sperm} / \mathrm{mL}$, and the oligozoospermic patient's seminal samples were diluted in 1:1 ( $\mathrm{vol} / \mathrm{vol}$ ) in PBS. The eppendorf with agarose (low melting point) was heated for 5 minutes at $90^{\circ}$ to $100^{\circ} \mathrm{C}$. Then it was placed in a water bath at $37^{\circ} \mathrm{C}$ by 5 minutes. Then, $20 \mu \mathrm{L}$ of diluted semen was added and homogenized. $10 \mu \mathrm{L}$ of this homogenate was placed on a pretreated slide with agarose (normal melting point) and covered with a $22 \times 22 \mathrm{~mm}$ cover slide. The slides were placed under refrigeration at $4^{\circ} \mathrm{C}$ for 7 minutes. Then the cover slides were gently removed and we added the acid solution $(20 \mu \mathrm{L} \mathrm{HCl}$ added to $2.5 \mathrm{~mL}$ of distilled water) for 7 minutes. After the removal of this solution, we added the lysis solution for 15 minutes. Then the lysis solution was removed, and the slide was placed in distilled water and alcohol (70\%. $90 \%$ and $100 \%$ ) for two minutes each. We left the slide for drying at room temperature, and then we stained it with Wright dye. We analyzed 500 sperm per slide to determine the DNA fragmentation index (DFI). There were five types of halos: big halo, medium halo, small halo, without halo and degraded. Big and medium halo are considered as spermatozoa with normal DNA fragmentation and small halo, without halo and degraded as fragmented DNA spermatozoa.

\section{Statistical Analysis}

The data was analyzed using the SPSS 22.0 software for windows (SPSS, Chicago, IL, USA). The data is presented as mean \pm standard deviation (SD). For the statistical comparison between the different groups, we tested the significance of difference using the Mann-Whitney test and the Kruskal-Wallis test. The regression and correlation analyses were performed using the Spearman 's correlation coefficient. The level of significance was set at $p<0.05$.

\section{RESULTS}

The age of the patients ranged from 19 to 59 years with a mean of $38.79 \pm 6.91$. We analyzed the seminal parameter and DFI of NORMO and ALTERED patients (Table 1). The values of concentration, progressive motility and normal morphology were significantly lower among the ALTERED patients $(p=0.000)$. The DFI value was significantly high among the ALTERED patients $(p=0.003)$. In addition, the ALTERED patients' ages were significantly higher when compared to the NORMO patients' ages $(p=0.004)$.

In our study, the NORMO patients had significantly higher values $(p=0.000)$ in concentration, progressive motility and normal morphology, and a significantly lower value in DFI $(p=0.003)$, when compared with other groups with oligozoospermia (Table 2). The same trend occurred in favor of patients with normal concentration, compared with the oligozoospermic group. Although the DFI value is low in normozoospermic patients (NORMO), when compared to patients with normal concentration, there were no significant differences between them. The patients with OLIGO SM had a significantly lower value $(p=0.000)$ in concentration, progressive motility and normal morphology; and significantly higher $(p=0.002)$ percentage of DFI when compared with the NORMO group (Table 2 ).

Table 3 shows the comparison of seminal parameters and DFI between the asthenozoospermic and the normozoospermic patients. The NORMO group presents concentration, progressive motility and normal morphology values significantly higher $(p=0.000)$ and significantly lower ages $(p=0.042)$ and DFI $(p=0.000)$; when compared to the other group. In addition, the patients with normal progressive motility had significantly higher concentration, progressive motility and normal morphology $(p=0.000)$, and a significantly lower DFI $(p=0.000)$, when compared with the group of asthenozoospermic patients. When comparing the NORMO group with patients with normal progressive motility, only the normal morphology group had significant differences $(3.76 \pm 1.42$ vs $4.67 \pm 1.65$ $p=0.000$, respectively). The ASTHENO group patients had significantly lower concentration, progressive motility and normal morphology values, and a significantly low percentage of DFI, when compared with the NORMO patients group.

In the present study, the NORMO group had concentration, progressive motility and normal morphology values significantly higher $(p=0.000)$, and significantly lower ages $(p=0.001)$ and DFI $(p=0.005)$, when compared with the teratozoospermic patients (Table 4 ). Although the DFI values were lower in NORMO compared with normal morphology patients, there were no significant differences between them (Table 4 ).

In table 5, we compared NORMO and oligoasthenoteratozoospermic patients (OAT). DFI was significantly higher in OAT compared with NORMO patients, $22.05 \pm 12.15$ vs $15.64 \pm 7.65, p=0.001$, respectively. 


\begin{tabular}{|c|c|c|c|}
\hline & $\begin{array}{c}\text { NORMO } \\
n=132 \\
\text { Mean } \pm \text { SD }\end{array}$ & $\begin{array}{c}\text { ALTERED } \\
n=286 \\
\text { Mean } \pm \text { SD }\end{array}$ & $p$ value \\
\hline Age & $37.26 \pm 6.76$ & $39.50 \pm 6.87$ & 0.004 \\
\hline Volume $(\mathrm{mL})$ & $2.85 \pm 0.95$ & $2.85 \pm 1.27$ & 0.357 \\
\hline Concentration $\left(\times 10^{6} / \mathrm{mL}\right)$ & $76.08 \pm 36.36$ & $53.41 \pm 39.38$ & 0.000 \\
\hline Progressive motility (\%) & $47.59 \pm 10.60$ & $26.72 \pm 15.55$ & 0.000 \\
\hline Normal morphology (\%) & $4.67 \pm 1.05$ & $2.77 \pm 1.28$ & 0.000 \\
\hline DFI (\%) & $15.64 \pm 7.65$ & $18.41 \pm 9.43$ & 0.003 \\
\hline
\end{tabular}

NORMO: Normozoospermic patients. ALTERED: patients with an altered parameter

Table 2. Descriptive statistic and comparison between group of oligozoospermia patients with normal concentration, and normozoospermic patients

\begin{tabular}{|c|c|c|c|c|c|}
\hline & \multicolumn{2}{|c|}{ OLIGOZOOSPERMIA } & \multirow{2}{*}{$\begin{array}{c}\text { CONC N } \\
n=366\end{array}$} & \multirow{2}{*}{$\begin{array}{c}\text { NORMO } \\
n=132\end{array}$} & \multirow[b]{2}{*}{$p$ value } \\
\hline & $\begin{array}{c}\text { OLIGO SM } \\
n=11\end{array}$ & $\begin{array}{c}\text { OLIGO M } \\
n=41\end{array}$ & & & \\
\hline Age & $37.09 \pm 6.30$ & $38.37 \pm 7.08$ & $38.89 \pm 6.92$ & $37.26 \pm 6.76$ & 0.178 \\
\hline Volume (mL) & $2.86 \pm 1.54$ & $2.88 \pm 1.26$ & $2.85 \pm 1.16$ & $2.85 \pm 0.95$ & 0.869 \\
\hline Concentration $(\times 106 / \mathrm{mL})$ & $2.20 \pm 1.46$ & $11.03 \pm 2.76$ & $67.88 \pm 37.14^{\mathrm{a}, \mathrm{d}}$ & $76.08 \pm 36.36^{b, c}$ & 0.000 \\
\hline Progressive motility (\%) & $17.98 \pm 12.62$ & $19.47 \pm 13.53$ & $35.32 \pm 16.73^{\mathrm{a}, \mathrm{d}}$ & $47.59 \pm 10.60^{b, c}$ & 0.000 \\
\hline Normal morphology (\%) & $1.82 \pm 1.47$ & $2.73 \pm 1.23$ & $3.49 \pm 1.49^{a, d}$ & $4.67 \pm 1.05^{b, c}$ & 0.000 \\
\hline DFI (\%) & $26.38 \pm 12.94$ & $19.81 \pm 11.40$ & $17.01 \pm 8.39^{\mathrm{a}, \mathrm{d}}$ & $15.64 \pm 7.65^{c}$ & 0.003 \\
\hline
\end{tabular}

OLIGO SM: Severe/Moderate oligozoospermia $\left(<5 \times 10^{6} / \mathrm{mL}\right)$. OLIGO M: Mild oligozoospermia (5 to $\left.<15 \times 10^{6} / \mathrm{mL}\right)$. CONC N: Normal Concentration ( $\left.\geq 15 \times 10^{6} / \mathrm{mL}\right)$. NORMO: Normozoospermic patients.

$p$ value between all the groups

a $p<0.01$ between group oligozoospermia (OLIGO SM and oligo $\mathrm{M}$ ) and normal concentration

${ }^{\mathrm{b}} p<0.05$ between normal concentration and normozoospermic patients.

${ }^{c} p<0.005$ between OLIGO SM and normozoospermic patients.

${ }^{\mathrm{d}} p<0.01$ between OLIGO SM and normal concentration.

Table 3. Descriptive statistic and comparison between group of asthenozoospermia, normal patients with progressive motility and normozoospermic patients

\begin{tabular}{|c|c|c|c|c|c|c|}
\hline & \multicolumn{3}{|c|}{ ASTHENOZOOSPERMIA } & \multirow{2}{*}{$\begin{array}{c}\text { NORMAL } \\
\text { MOTILITY } \\
\text { n=229 }\end{array}$} & \multirow{2}{*}{$\begin{array}{c}\text { NORMO } \\
n=132\end{array}$} & \multirow[b]{2}{*}{$\boldsymbol{p}$} \\
\hline & $\begin{array}{l}\text { ASTHENO S } \\
n=41\end{array}$ & $\begin{array}{c}\text { ASTHENO MO } \\
n=66\end{array}$ & $\begin{array}{l}\text { ASTHENO M } \\
n=82\end{array}$ & & & \\
\hline Age & $40.20 \pm 6.86$ & $39.95 \pm 7.34$ & $39.02 \pm 7.06$ & $38.12 \pm 6.69^{d}$ & $37.26 \pm 6.76^{c}$ & 0.042 \\
\hline Volume $(\mathrm{mL})$ & $2.84 \pm 1.50$ & $2.67 \pm 1.15$ & $2.93 \pm 1.31$ & $2.87 \pm 1.06$ & $2.85 \pm 0.95$ & 0.449 \\
\hline Concentration $\left(\times 10^{6} / \mathrm{mL}\right)$ & $34.11 \pm 31.40$ & $41.64 \pm 33.83$ & $60.64 \pm 47.16$ & $70.74 \pm 35.75^{\mathrm{a}, \mathrm{d}}$ & $76.08 \pm 36.36^{c}$ & 0.000 \\
\hline Progressive Motility (\%) & $5.75 \pm 2.80$ & $15.30 \pm 2.92$ & $25.40 \pm 3.46$ & $46.27 \pm 10.47^{\mathrm{a}, \mathrm{d}}$ & $47.59 \pm 10.60^{c}$ & 0.000 \\
\hline Normal Morphology (\%) & $2.22 \pm 1.21$ & $2.97 \pm 1.36$ & $3.19 \pm 1.58$ & $3.76 \pm 1.42^{\mathrm{a}, \mathrm{d}}$ & $4.67 \pm 1.05^{\mathrm{b}, \mathrm{c}}$ & 0.000 \\
\hline DFI (\%) & $23.09 \pm 11.45$ & $18.78 \pm 10.74$ & $17.88 \pm 9.56$ & $16.06 \pm 7.16^{a, d}$ & $15.64 \pm 7.65^{c}$ & 0.000 \\
\hline
\end{tabular}

ASTHENO S: Severe asthenozoospermia (<10\%). ASTHENO MO: Moderate asthenozoospermia (10 to <20\%). ASTHENO M: Mild asthenozoospermia $(20$ to $<32 \%)$. NORMAL MOTILITY $(\geq 32 \%)$. NORMO: Normozoospermic patients.

$p$ value between all the groups

${ }^{a} p<0.005$ between group oligozoospermia (ASTEHNO S, ASTHENO MO and ASTHENO M) and normal progressive motility.

${ }^{\mathrm{b}} p=0.000$ between normal progressive motility and normozoospermic patients.

${ }^{c} p<0.01$ between ASTHENO $S$ and normozoospermic patients.

${ }^{\mathrm{d}} p<0.05$ between ASTHENO $\mathrm{S}$ and normal progressive motility 
Table 4. Descriptive statistic and comparison between Teratozoospermic patients, patients with normal morphology and normozoospermic patients

\begin{tabular}{|c|c|c|c|c|}
\hline & $\begin{array}{c}\text { TERATO } \\
n=222\end{array}$ & $\begin{array}{c}\text { NORMAL } \\
\text { MORPHOLOGY } \\
n=196\end{array}$ & $\begin{array}{c}\text { NORMO } \\
n=132\end{array}$ & $\boldsymbol{p}$ \\
\hline Age & $39.83 \pm 6.77$ & $37.61 \pm 6.89^{a}$ & $37.26 \pm 6.76^{c}$ & 0.001 \\
\hline Volume (mL) & $2.83 \pm 1.23$ & $2.87 \pm 1.10$ & $2.85 \pm 0.95$ & 0.548 \\
\hline Concentration & $51.00 \pm 34.34$ & $71.41 \pm 42.82^{\mathrm{a}}$ & $76.08 \pm 36.36^{c}$ & 0.000 \\
\hline Progressive Motility (\%) & $28.41 \pm 16.48$ & $38.87 \pm 16.26^{a}$ & $47.59 \pm 10.60^{\mathrm{b}, \mathrm{c}}$ & 0.000 \\
\hline Morphology (\%) & $2.25 \pm 0.80$ & $4.64 \pm 1.04^{a}$ & $4.67 \pm 1.05^{c}$ & 0.000 \\
\hline DFI (\%) & $17.96 \pm 9.23$ & $17.04 \pm 8.71$ & $15.64 \pm 7.65^{c}$ & 0.053 \\
\hline
\end{tabular}

TERATO: Teratozoospermic patients. NORMO: Normozoospermic patients.

$p$ value between all the groups

a $p<0.005$ between teratozoospermic and normal morphology patients.

${ }^{\mathrm{b}} p=0.000$ between normal morphology and normozoospermic patients

${ }^{c} p<0.05$ value between teratozoospermic and normozoospermic patients.

Table 5. Comparison of the DNA fragmentation index (DFI) between normozoospermic and oligoasthenoteratozoospermic (OAT)

\begin{tabular}{|l|c|c|c|}
\hline & NORMO (n= 132) & OAT (n= 37) & p \\
\hline DFI & $15.64 \pm 7.65$ & $22.05 \pm 12.15$ & 0.001 \\
\hline
\end{tabular}

Spearman's correlation analysis indicated that the progressive motility ( $r=-0.162 p=0.001$ ) (Figure 1 ) and normal morphology ( $r=-0.100 p=0.040$ ) (Figure 2) had significant negative correlations with DFI. Age $(r=0.257$ $p=0.000$ ) had a positive correlation with DFI (Figure 3 ). We did not find a significant correlation between age and sperm concentration $(r=-0.17 p=0.732)$.

\section{DISCUSSION}

The semen conventional analysis (sperm concentration, progressive motility and morphology) is used to assess fertility in men. However, the lack of correlation with the fertilizing potential make necessary to introduce new

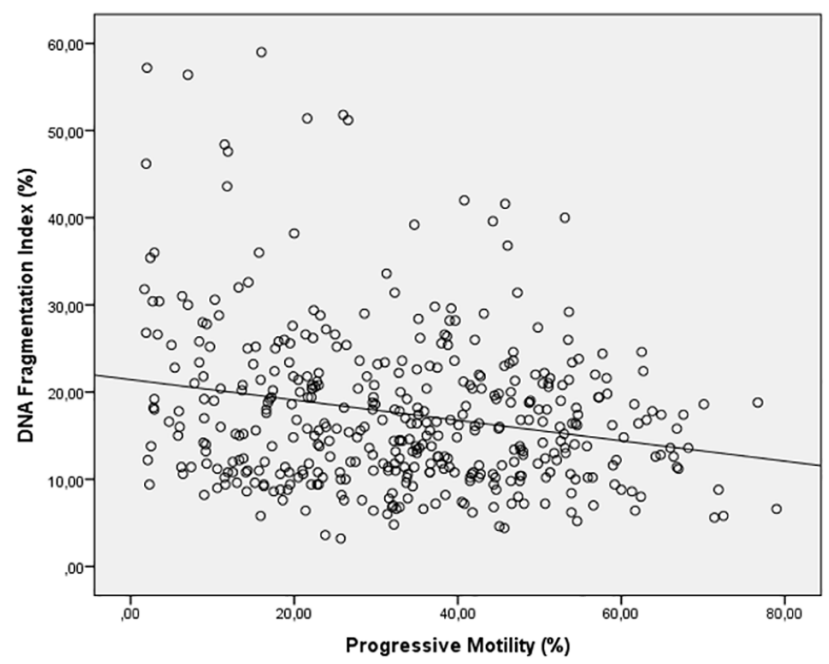

Figure 1. Correlation between Progressive motility and DFI. Individual data points and the regression line are shown. Spearman's correlation coefficient $=-0.162$ $p=0.001$.

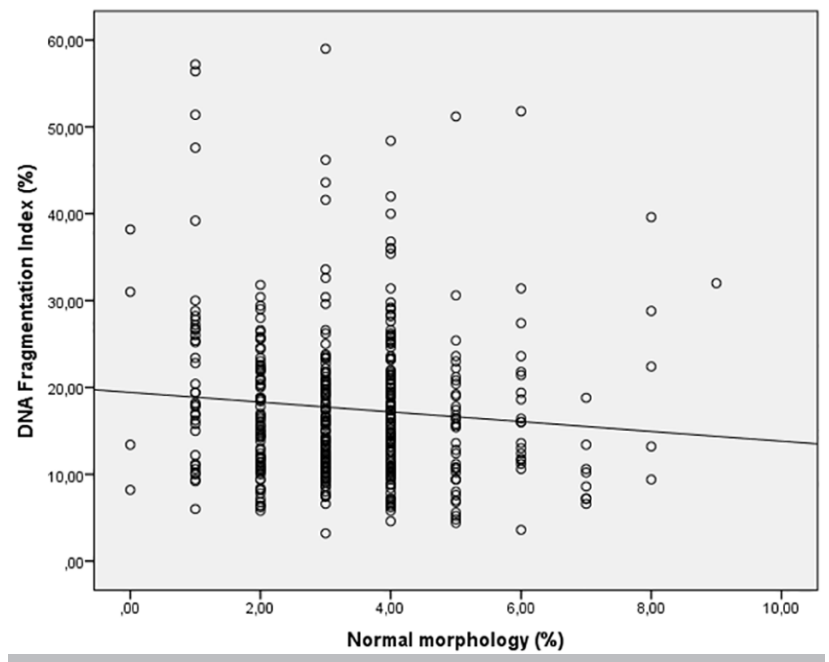

Figure 2. Correlation between Normal morphology and DFI. Individual data points and the regression line are shown. Spearman's correlation coefficient $=-0.100$ $p=0.040$.

routine tests, such as sperm DNA fragmentation. High DFI values are correlated with reduced fertilization rates, early development embryo, bad embryo quality, low pregnancy rates and higher rates of spontaneous miscarriage (Bungum et al., 2007; Lewis et al., 2013; Simon et al., 2014). For these reasons, various authors have recommended the introduction of sperm DNA fragmentation analysis as a routine and complementary test in semen analysis (Lewis \& Aitken, 2005; Fortunato et al., 2013). In this study, we uses the SCD test due its high sensitivity to detect sperm with DNA fragmentation (Chohan et al., 2006; Zhang et al., 2010; Liffner et al., 2019).

This study found that sperm concentration, progressive motility and normal morphology were significantly lower in 


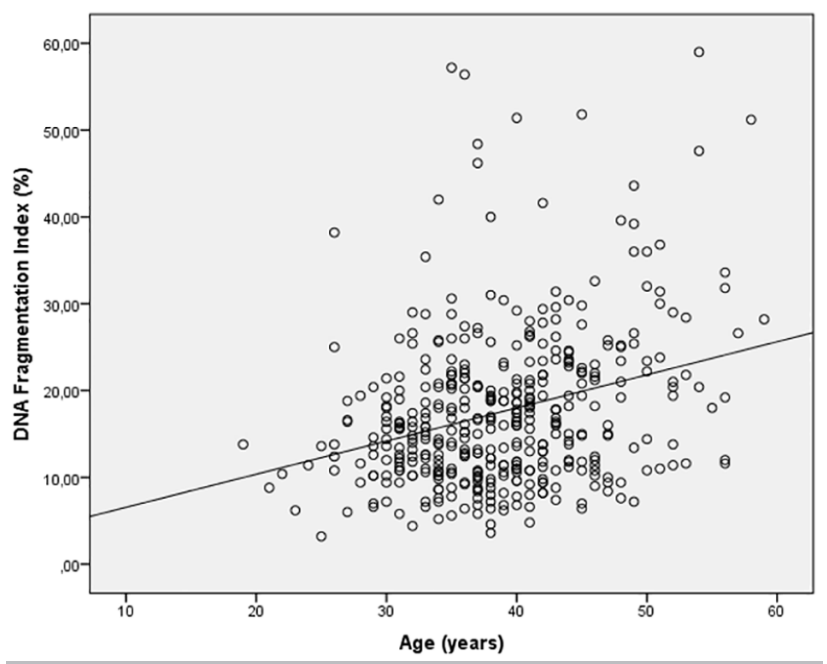

Figure 3. Correlation between age and DFI. Individual data points and the regression line are shown. Spearman's correlation coefficient $=0.257 p=0.000$.

ALTERED patients, when compared with NORMO patients, while semen volume did not differ (Table 1). Several studies have confirmed the correlation between altered semen parameters and high ROS concentrations (Agarwal et al., 2014; Majzoub et al., 2018; 2019); and up to $80 \%$ of infertile men have elevated seminal ROS (Agarwal \& Sekhon, 2014). Likewise, the current evidence recognizes oxidative stress as an important cause of sperm DNA fragmentation (Aitken \& De luliis, 2010; Iommiello et al., 2015). Thus, we believe that high DFI values among the ALTERED patients is due to high concentrations of ROS produced by decreased semen quality in these patients. These results are consistent with other studies from Peru, such as those of Acosta \& Dueñas (2014), which found a mean DFI value among ALTERED patients to be significantly higher than in the NORMO patients (22.95 \pm 12.25 vs $14.39 \pm 9.06)$; and Acosta et al. (2016) found significant differences in the mean value of DFI between ALTERED and NORMO patients $(21.51 \pm 14.18$ vs $14.08 \pm$ 7.08 , respectively). Similar results were reported by other studies evaluating fertile and infertile patients using the SCD test (Fernández et al., 2005; Chohan et al., 2006; Evgeni et al., 2015; Wiweko \& Utami, 2017; Majzoub et al., 2019) and other tests (Sergerie et al., 2005; Chohan et al., 2006; Sheikh et al., 2008; Mayorga-Torres et al., 2013; Di Santo et al., 2016). On the other hand, the study by Khalili et al. (2006) did not find significant differences in the value of DFI between fertile and infertile patients using the acridine orange staining test. We believe that the lack of correlation with DFI in this study is due to the assay used. The acridine orange staining assay is questionable, and is not recommended as a screening test for sperm quality and functional capacity due its very low clinical significance for infertility testing, and lack of relationship with other test, such as SCSA, TUNEL and SCD (Chohan et al., 2006).

We found that age has a high significance in ALTERED patients when compared with NORMO patients (39.50 \pm 6.87 vs $37.26 \pm 6.76$, respectively) (Table 1 ). Male aging is associated with infertility, semen altered parameters and sperm DNA fragmentation. Aging causes accumulation of ROS, leading to increased oxidative stress that induces lipid peroxidation and further ROS generation in the mitochondria (Gunes et al., 2016). An excessive amount of ROS and decreased antioxidant capacity in the course of aging may induce apoptosis or oxidative damage to DNA.
Our results are consistent with the study from Majzoub et al. (2019), and discordant with the studies from Acosta \& Dueñas (2014) and Acosta et al. (2016).

Our study shows significant differences in the DFI between normozoospermic and oligozoospermic patients (Table 2). Our data is congruent to several studies (Varshini et al., 2011; Aydos et al., 2015; Choucair et al., 2016). A possible explanation for this relationship is the increased apoptosis of mature spermatozoa. Apoptosis controls the overproduction of male gametes (Sakkas et al., 1999). Increased levels of ROS are correlated with increased apoptosis of mature spermatozoa. (Agarwal \& Sekhon, 2011). Oxidative stress-induced DNA damage may accelerate the process of germ cell apoptosis, leading to a decline in sperm count (Agarwal et al., 2003).

Progressive motility is one of the important parameters involved in sperm fertilizing capacity. This study shows DFI significant differs between normozoospermic patients and the asthenozoospermic group (Table 3 ). Our results are consistent with several studies. Belloc et al. (2014) determined that sperm motility is the seminal parameter that is most intimately related to sperm DNA fragmentation. In their study, they found a significant high level of DFI in males with asthenozoospermia alone when compared to oligozoospermia, or isolated teratozoospermia. Elbashir et al. (2018) found a significant negative correlation between DFI and progressive motility between infertile asthenozoospermic men and men with proven fertility. On the other hand, Varshini et al. (2011) reported a statically non-significant difference in DFI using TUNEL between asthenozoospermic patients and normozoospermic patients, despite having high median distribution. A possible explanation of the association between DFI and asthenozoospermia can be found in the development of the flagellum in the spermatogenesis. Cho et al. (2001) showed that the DNA compaction (using protamine or transition protein insufficiency models) is associated with development of an abnormal flagellum and defective motility. Another reason that explains this correlation, may be due to the increased oxidative stress causing sperm DNA damage, and in turn induce the lipid peroxidation of the sperm membrane, which results in oxidation of polyunsaturated fatty acids in the plasma membrane and the formation of malondialdehyde (MDA), thereby leading to structural and functional damage to the spermatozoa (Agarwal \& Said, 2005). High levels of MDA is correlated with high DFI, both having a negative correlation with the progressive motility (Dorostghoal et al., 2016). Thus, high concentration of ROS can cause decreased sperm motility due to the damage to the axonemal structure or the reduction in intracellular adenosine triphosphate (Tsunoda et al., 2012). The decreased sperm motility has also been explained by apoptosis. Oxidative stress causes the generation of spermatozoa with poorly remodelled chromatin. These defective cells have a tendency to enter in an apoptotic pathway associated with motility loss (Aitken \& Koppers, 2011).

Teratozoospermia presents a high phenotypic variability and limited information is available about its pathophysiological mechanism. Morphological anomalies of the spermatozoa play a very important role in determining the male fertility potential. DNA damage is correlated with different abnormal shape of the head and flagellum of sperms, being the anomaly of the head that presents a highly significant DFI value (Eskandari et al., 2017). In this study, we found a significant DFI correlation between teratozoospermic and normozoospermic patients (Table 4). Previous studies have demonstrated a positive correlation between teratozoospermia and DFI (Varshini et al., 2011; Garcia-Ferreyra et al., 2014; Aydos et al., 
2015); and other studies have not reported a significant relationship between these parameters (Avendaño et al., 2009; Choucair et al., 2016). One of the processes that explains this relationship is the incomplete replacement of histone by protamine, which induces abnormal chromatin condensation, producing deformations of the nucleus and overall head shape in the sperm (Ma et al., 2019). Another explanation may be the abnormal apoptosis causing oxidative stress. The abnormal apoptosis may cause the persistence of abnormal spermatozoa that are marked for elimination, thereby increasing teratozoospermia (Sakkas et al., 1999). Aydos et al. (2015) determined that the positive correlation between sperm DNA damage and impaired sperm morphology might be associated with the fact that sperm DNA damage leads to impairment in the sperm chromatin structure.

Our results indicate that DFI is significantly higher in men with OAT when compared with normozoospermic men (Table 5). Several studies have investigated the association between DFI and conventional seminal parameters. Most of these studies are consistent with our results (Varshini et al., 2011, Acosta et al., 2015; Aydos et al., 2015; Choucair et al., 2016), confirming that male infertility is associated with poor sperm DNA integrity.

The present data demonstrated a statically significant inverse correlation between the DFI percentage, sperm progressive motility and sperm normal morphology (Figure $1,2)$. We did not find a significant correlation with sperm concentration. Many studies have reported a significant negative correlation between DFI and semen parameters, mainly concentration (Velez de la Calle et al., 2008; Acosta \& Dueñas, 2014; Aydos et al., 2015; Acosta et al., 2015; Choucair et al; 2016), progressive motility (Sheikh et al., 2008; Velez de la Calle et al., 2008; Acosta \& Dueñas, 2014; Acosta et al; 2015; Aydos et al., 2015; Evgeni et al., 2015; Choucair et al; 2016; Elbashir et al., 2018) and normal morphology (Velez de la Calle et al., 2008; Fortunato et al., 2013; Acosta \& Dueñas, 2014; GarcíaFerreyra et al., 2014; Aydos et al., 2015), alone or in combination. On the other hand, the study by Khalili et al. (2006) did not find correlations between DFI and sperm concentration, progressive motility and normal morphology using the acridine orange staining test. Likewise, we found a significant positive correlation between DFI and age, but this is considered a weak correlation $(r=0.257)$ (Figure 3 ). These correlations are similar to those reported by other authors: Acosta \& Dueñas (2014) $r=0.198 p=$ 0.009, García-Ferreyra et al. (2014) $r=0.106 p=0.0001$, Acosta et al. (2015) $r=0.198 p=0.009$ and Petersen et al. (2018) $r=0.14 p=0.002$. Other studies found $a$ strong correlation between sperm DNA fragmentation and age; Plastira et al. (2007) $r=0.558 p<0.001$, and other authors did not find significant correlations (Winkle et al., 2009; Brahem et al., 2011). Petersen et al. (2018) concluded that unfortunately not all studies follow these statistical analyzes, which makes it difficult to interpret this data.

In conclusion, our results suggest that an abnormal spermogram not only reflects altered spermatogenesis but also a negative effect on sperm DNA, and high DFI is accompanied by significant impairment to all seminal parameters.

\section{CONFLICTS OF INTEREST}

The authors have no conflict of interest to declare.

\section{Corresponding author:}

Acosta Campos Láyonal Germán

In Vitro Gestar

Chiclayo, Perú

E-mail: acostaclg@gmail.com

\section{REFERENCES}

Acosta LG, Dueñas JC. Correlation between semen parameters and sperm DNA fragmentation in men attending a fertility center. Rev Iberoam Fert Rep Hum. 2014;31:4452.

Acosta L, Rivas C, Chiscul L, Díaz J. Correlation between semen parameters, sperm DNA fragmentation and oxidative stress in patients attending in a fertility center in northern Perú. Rev Iberoam Fert Rep Hum. 2015;32:24-34.

Agarwal A, Saleh RA, Bedaiwy MA. Role of reactive oxygen species in the pathophysiology of human reproduction. Fertil Steril. 2003;79:829-43. PMID: 12749418 DOI: $10.1016 / \mathrm{S} 0015-0282(02) 04948-8$

Agarwal A, Allamaneni S. Sperm DNA damage assessment: a test whose time has come. Fertil Steril. 2005;84:850-3. PMID: 16213833 DOI: 10.1016/j.fertnstert.2005.03.080

Agarwal A, Said TM. Oxidative stress, DNA damage and apoptosis in male infertility: a clinical approach. BJU Int. 2005;95:503-7. PMID: 15705068 DOI: $10.1111 / j .1464-$ 410X.2005.05328.x

Agarwal A, Sekhon LH. Oxidative stress and antioxidants for idiopathic oligoasthenoteratospermia: it is justified? Indian J Urol 2011. 2011;27:74-85. PMID: 21716893 DOI: $10.4103 / 0970-1591.78437$

Agarwal A, Sharma RK, Sharma R, Assidi M, Abuzenadah AM, Alshahrani S, Durairajanayagam D, Sabanegh. Characterizing semen parameters and their association with reactive oxygen species in infertile men. Reprod Biol Endocrinol. 2014;12:33. PMID: 24885775 DOI: 10.1186/14777827-12-33

Agarwal A, Majzoub A, Esteves S, Ko E, Ramasamy R, Zini A. Clinical utility of sperm DNA fragmentation testing: practice recommendations based on clinical scenarios. Transl Androl Urol. 2016;5:935-50. PMID: 28078226 DOI: $10.21037 /$ tau.2016.10.03

Aitken RJ, De luliis GN. On the possible origins of DNA damage in human spermatozoa. Mol Hum Reprod. 2010;16:313. PMID: 19648152 DOI: 10.1093/molehr/gap059

Aitken RJ, Koppers AJ. Apoptosis and DNA damage in human spermatozoa. Asian J Androl. 2011;13:36-42. PMID: 20802502 DOI: 10.1038/aja.2010.68

Aktan G, Dogru-Abbasoglu S, Kücükgergin C, Kadioglu A, Ozdemirler-Erata G, Kocak-Toker N. Mystery of idiopathic male infertility: is oxidative stress an actual risk? Fertil Steril. 2013;99:1211-5. PMID: 23254182 DOI: 10.1016/j. fertnstert.2012.11.045. 
Alahmar AT. Role of oxidative stress in male infertility: an updated review. J Hum Reprod Sci. 2019;12:4-18. PMID: 31007461 DOI: $10.4103 /$ jhrs.JHRS_150_18

Avendaño C, Franchi A, Taylor S, Morshedi M, Bocca S, Oehninger $\mathrm{S}$. Fragmentation of DNA in morphologically normal human spermatozoa. Fertil Steril. 2009;91:1077-84. PMID: 18440529 DOI: 10.1016/j.fertnstert.2008.01.015.

Aydos OS, Yükselten Y, Kaplan F, Sunguroğlu A, Aydos K. Analysis of the correlation between sperm DNA integrity and conventional semen parameters in infertile men. Turk J Urol. 2015;41:191-7. PMID: 26623148 DOI:10.5152/ tud.2015.98475

Belloc S, Benkhalifa M, Cohen-Bacrie M, Dalleac A, Chahine $\mathrm{H}$, Amar $\mathrm{E}$, Zini A. Which isolated sperm abnormality is most related to sperm DNA damage in men presenting for infertility evaluation. J Assist Reprod Genet. 2014;31:52732. PMID: 24566945 DOI: 10.1007/s10815-014-0194-3.

Borges Junior E, Zanetti BF, Setti AS, Braga DP, Provenza $R R$, Iaconelli Junior A. Sperm DNA fragmentation is correlated with poor embryo development, lower implantation rate, and higher miscarriage rate in reproductive cycles of non-male factor infertility. Fertil Steril. 2019;112:483-90. PMID: 31200969 DOI: 10.1016/j.fertnstert.2019.04.029

Brahem S, Mehdi M, Elghezal $H$, Saad A. The effects of male aging on semen quality, sperm DNA fragmentation and chromosomal abnormalities in an infertile population. J Assist Reprod Genet. 2011;28:425-32. PMID: 21287403. DOI: $10.1007 / \mathrm{s} 10815-011-9537-5$

Bungum $M$, Humaidan $P$, Axmon A, Spano M, Bungum $L$, Erenpreiss J, Giwercman A. Sperm DNA integrity assessment in prediction of assisted reproduction technology outcome. Hum Reprod. 2007;22:174-9. PMID: 16921163 DOI: $10.1093 /$ humrep/del326.

Cho C, Willis WD, Goulding EH, Jung-Ha H, Choi YC, Hecht NB, Eddy EM. Haploinsufficiency of protamine-1 or -2 causes infertility in mice. Nat Genet. 2001;28:82-6. PMID: 11326282 DOI: $10.1038 / n g 0501-82$

Chohan KR, Jeanine T, Griffin JT, Lafromboise M, De Jonge CJ, Carrel DT. Comparison of chromatin assays for DNA fragmentation evaluation in human sperm. J Androl. 2006;27:53-9. PMID: 160400078 DOI: 10.2164/jandrol.05068

Choucair FB, Rachkidi EG, Raad GC, Saliba EM, Zeidan NS, Jounblat RA, Jaoude IF, Hazzouri MM. High level of DNA fragmentation in sperm of Lebanese infertile men using Sperm Chromatin Dispersion test. Middle East Fertil Soc J. 2016;21:269-76. DOI: 10.1016/j.mefs.2016.06.005

De Neubourg D, Van Duijnhoven, NT, Nelen WL, D'Hooghe TM. Dutch translation of the ICMART-WHO revised glossary on ART terminology. Gynecol Obstet Invest. 2012;74:23348. PMID: 23146953 DOI: 10.1159/000342876

Di Santo M, Tarozzi N, Nadalini M, Borini A. Analysis of sperm DNA fragmentation and aneuploidy in 109 infertile patients: are the two parameters correlated? Gynecol Obstet Case Rep. 2016;2:2. DOI: 10.21767/24718165.1000031
Dorostghoal M, Kazeminejad SR, Shahbazian N, Pourmehdi $M$, Jabbari $A$. Oxidative stress status and sperm DNA fragmentation in fertile and infertile men. Andrologia. 2017;49:e12762. PMID: 28124476 DOI: 10.1111/ and. 12762

Durairajanayagam D. Lifestyle causes of male infertile. Arab J Urol. 2018;16:10-20. PMID: 29713532 DOI: 10.1016/j.aju.2017.12.004

Elbashir S, Magdi Y, Rashed A, Ibrahim MA, Edris Y, Abdelaziz AM. Relationship between sperm progressive motility and DNA integrity in fertile and infertile men. Middle East Fertil Soc J. 2018;23:195-8. DOI: 10.1016/j. mefs.2017.12.002

Eskandari N, Tavalaee M, Zohrabi D, Nasr-Esfahani M. Association between total globozoospermia and sperm chromatin defects. Andrologia. 2017;50:e12843. PMID: 28660655 DOI: 10.1111 /and. 12843

Evgeni E, Lymberopoulos G, Gazouli M, Asimakopoulos B. Conventional semen parameters and DNA fragmentation in relation to fertility status in a Greek population. Eur J Obstet Gynecol Reprod Biol. 2015;188:17-23. PMID: 25770843 DOI: 10.1016/j.ejogrb.2015.02.026

Feijó CM, Esteves SC. Diagnostic accuracy of sperm chromatin dispersion test to evaluate sperm deoxyribonucleic acid damage in men with unexplained infertility. Fertil Steril. 2014;101:58-63.e3. PMID: 24140035 DOI: 10.1016/j. fertnstert.2013.09.002

Fernández JL, Muriel L, Rivero MT, Goyanes V, Vazquez R, Alvarez JG. The sperm chromatin dispersion test: a simple method for the determination of sperm DNA fragmentation. J Androl. 2003;24:59-66. PMID: 12514084 DOI: 10.1002/j.1939-4640.2003.tb02641.x

Fernández JL, Muriel L, Goyanes V, Segrelles E, Gosálvez J, Enciso M, LaFromboise M, De Jonge C. Simple determination of human sperm DNA fragmentation with an improved sperm Chromatin dispersion test. Fertil Steril. 2005;84:833-42. PMID: 16213830 DOI: $10.1016 / j . f e r t n-$ stert.2004.11.089

Fortunato A, Leo R, Casale S, Nacchia G, Liguori F, Tosti E. Sperm DNA fragmentation assay correlate with sperm abnormal morphology and the pregnancy outcome. J IVF Reprod Med Genet. 2013;1:1. DOI: 10.4172/23754508.1000101

García-Ferreyra J, Villegas L, Romero R, Zavala P, Hilario $R$, Casafranca G, Dueñas-Chacón J. Sperm DNA fragmentation is significantly increased in those men with morphologically abnormal spermatozoa. JFIV Reprod Med Genet. 2014;2:131. DOI: $10.4172 / 2375-4508.1000131$

Gosálvez J, López-Fernández C, Fernández JL, Esteves SC, Johnston SD. Unpacking the mysteries of sperm DNA fragmentation: Ten frequently asked questions. J Reprod Biotechnol Fert. 2015;4:1-16. DOI: $10.1177 / 2058915815594454$

Gunes S, Hekim GN, Arslan MA, Asci R. Effects of aging on the male reproductive system. J Assist Reprod Genet. 2016;33:441-54. PMID: 26867640 DOI: 10.1007/s10815016-0663-y. 
Homa ST, Vessey W, Perez-Miranda A, Riyait T, Agarwal A. Reactive oxygen species (ROS) in human semen: determination of a reference range. ] Assist Reprod Genet. 2015;32:757-64. PMID: 25749739 DOI: 10.1007/s10815015-0454-x

Iommiello VM, Albani E, Di Rosa A, Marras A, Menduni $F$, Morreale G, Levi SL, Pisano B, Levi-Setti PE. Ejaculate oxidative stress is related with sperm DNA fragmentation and round cells. Int J Endocrinol. 2015;2015:321901. PMID: 25802519 DOI: $10.1155 / 2015 / 321901$

Ioannou $D$, Miller D, Griffin D, Tempest $H$. Impact of sperm DNA chromatin in the clinic. J Assist Reprod Genet. 2016;33:157-66. PMID: 26678492 DOI: 10.1007/s10815015-0624-x

Kadioglu A, Ortac $M$. The role of sperm DNA testing on male infertility. Transl Androl Urol. 2017;6(Suppl 4):S600-S3. PMID: 29082186 DOI: 10.21037/tau.2017.03.82

Khalili MA, Aghaie-Maybodi F, Anvari M, Talebi AR. Sperm nuclear DNA in ejaculates of fertile and infertile men: correlation with semen parameters. Urol J Tehran. 2006;3:154-9.

Kim SY, Kim HJ, Lee BY, Park SY, Lee HS, Seo JT. Y chromosome microdeletions in infertile men with non-obstructive azoospermia and severe oligozoospermia. J Reprod Infertil. 2017;18:307-15. PMID: 29062795

Kumar N, Singh AK. Trends of male factor infertility, an important cause of infertility: a review of literature. J Hum Reprod Sci. 2015;8:191-6. PMID: 26752853 DOI: 10.4103/0974-1208.170370

Lewis SE, Aitken RJ. DNA damage to spermatozoa has impacts on fertilization and pregnancy. Cell Tissue Res. 2005;322:33-41. PMID: 15912407 DOI: $10.1007 / s 00441-$ 005-1097-5

Lewis SE, Agbaje I, Alvarez J. Sperm DNA tests as useful adjuncts to semen analysis. Syst Biol Reprod Med. 2008;54:111-25. PMID: 18570047 DOI: $10.1080 / 19396360801957739$

Lewis SE, Aitken RJ, Conner SJ, De luliis G, Evenson DP, Henkel R, Giwercman A, Gharagozloo P. The impact of sperm DNA damage in assisted conception and beyond: recent advances in diagnosis and treatment. Reprod Biomed Online. 2013;27:325-37. PMID: 23948450 DOI: 10.1016/j.rbmo.2013.06.014

Liffner S, Pehrson I, García-Calvo L, Nedstrand E, Zalavary $\mathrm{S}$, Hammar $\mathrm{M}$, Rodríguez-Martínez $\mathrm{H}$, Álvarez-Rodríguez M. Diagnostics of DNA fragmentation in human spermatozoa: Are sperm chromatin structure analysis and sperm chromatin dispersion tests (SCD-HaloSpermG ${ }^{\circledR}$ ) comparable? Andrologia. 2019;51:e13316. PMID: 31099901 DOI: $10.1111 /$ and.13316

Ma Y, Xie N, Li Y, Zhang B, Xie D, Zhang W, Li Q, Yu H, Zhang $Q$, Ni $Y$, Xie $X$. Teratozoospermia with amorphous sperm head associate with abnormal chromatin condensation in a Chinese family. Syst Biol Reprod Med. 2019;65:61-70. PMID: 30452285 DOI: 10.1080/19396368.2018.1543481
Majzoub A, Arafa M, Mahdi M, Agarwal A, Al Said S, Emadi IA, El Ansari W, Alattar A, Rumaihi KA, Elbardisi H. Oxidation-reduction potential and sperm DNA fragmentation, and their associations with sperm morphological anomalies amongst fertile and infertile men. Arab J Urol. 2018;16:8795. PMID: 29713539 DOI: 10.1016/j.aju.2017.11.014

Majzoub A, Arafa M, El Ansari W, Mahdi1 M, Agarwal A, Al-Said S, Elbardisi $\mathrm{H}$. Correlation of oxidation reduction potential and total motile sperm count: its utility in the evaluation of male fertility potential. Asian J Androl. 2019;22:317-22. PMID: 31339113 DOI: 10.4103/aja. aja_75_19

Mayorga-Torres BJM, Cardona-Maya W, Cadavid Á, Camargo M. Evaluation of sperm functional parameters in normozoospermic infertile individuals. Actas Urol Esp. 2013;37:221-7. PMID: 23246107: 10.1016/j.acuro.2012.06.008

Moustafa MH, Sharma RK, Thornton J, Mascha E, Abdel-Hafez MA, Thomas Junior AJ, Agarwal A. Relationship between ROS production, apoptosis and DNA denaturation in spermatozoa from patients examined for infertility. Hum Reprod. 2004;19:129-38. PMID: 14688171 DOI: 10.1093/ humrep/deh024

Oliva A, Spira A, Multigner L. Contribution of environmental factors to the risk of male infertility. Hum Reprod. 2001;16:1768-76. PMID: 11473980 DOI: 10.1093/humrep/16.8.1768

Petersen CG, Mauri AL, Vagnini LD, Renzi $A$, Petersen $B$, Mattila M, Comar V, Ricci J, Dieamant F, Oliveira JB, Baruffi $R L$, Franco Junior JG. The effects of male age on sperm DNA damage: an evaluation of 2,178 semen samples. JBRA Assist Reprod. 2018;22:323-30. PMID: 30106542 DOI: $10.5935 / 1518-0557.20180047$

Plastira K, Msaouel P, Angelopoulou R, Zanioti K, Plastiras $A$, Pothos A, Bolaris S, Paparisteidis N, Mantas D. The effects of age on DNA fragmentation, chromatin packaging and conventional semen parameters in spermatozoa of oligoasthenoteratozoospermic patients. J Assist Reprod Genet. 2007;24:437-43. PMID: 17768675 DOI: 10.1007/ s10815-007-9162-5

Quintero-Vásquez G, Bermúdez-Cruz R, Castillo-Cadena J. Male infertility and spermatic DNA fragmentation: a current problem. TIP Rev Esp Cienc Quím Biol. 2015;18:144-51.

Rajeev SK, Reddy KV. Sperm membrane protein profiles of fertile and infertile men: identification and characterization of fertility-associated sperm antigen. Hum Reprod. 2004;19:234-42. PMID: 14747160 DOI: $10.1093 /$ humrep/deh066

Sakkas D, Mariethoz E, Manicardi G, Bizzaro D, Bianchi PG, Bianchi U. Origin of DNA damage in ejaculated human spermatozoa. Rev Reprod. 1999;4:31-7. PMID: 10051100 DOI: $10.1530 /$ ror.0.0040031

Sakkas D, Moffatt O, Manicardi GC, Mariethoz E, Tarozzi $\mathrm{N}$, Bizzaro D. Nature of DNA damage in ejaculated human spermatozoa and the possible involvement of apoptosis. Biol Reprod. 2002;66:1061-PMID: 11906926 DOI: 10.1095/biolreprod66.4.1061 
Sergerie M, Laforest G, Bujan L, Bissonnette F, Bleau G. Sperm DNA fragmentation: threshold value in male fertility. Hum Reprod. 2005;20:3446-51. PMID: 16085665 DOI: $10.1093 /$ humrep/dei231

Shamsi MB, Kumar R, Dada R. Evaluation of nuclear DNA damage in human spermatozoa in men opting for assisted reproduction. Indian J Med Res. 2008;127:115-23. PMID: 18403788

Shamsi MB, Venkatesh S, Kumar R, Gupta NP, Malhotra N, Singh N, Mittal S, Arora S, Arya DS, Talwar P, Sharma RK, Dada R. Antioxidant levels in blood and seminal plasma and their impact on sperm parameters in infertile men. Indian J Biochem Biophys. 2010;47:38-43. PMID: 21086753

Sharma RK, Said T, Agarwal A. Sperm DNA damage and its clinical relevance in assessing reproductive outcome. Asian J Androl. 2004;6:139-48. PMID: 15154089

Sheikh N, Amiri I, Farimani M, Najafi R, Hadeie J. Correlation between sperm parameters and sperm DNA fragmentation in fertile and infertile men. Iran J Reprod Med. 2008;6:13-8.

Simon L, Murphy K, Shamsi MB, Liu L, Emery B, Aston KI, Hotaling J, Carrell DT. Paternal influence of sperm DNA integrity on early embryonic development. Hum Reprod. 2014;29:2402-12. PMID: 25205757 DOI: 10.1093/humrep/deu228

Spiropoulos J, Turnbull DM, Chinnery PF. Can mitochondrial DNA mutations cause sperm dysfunction? Mol Hum Reprod. 2002;8:719-21. PMID: 12149402 DOI: 10.1093/ molehr/8.8.719

Tandara M, Bajic A, Tandara L, Sunj M, Jurisic Z, Jukic M. Correlation between proportions of sperm with DNA fragmentation assessed by Halosperm test and values of standard quality parameters of semen and possible impact in embryo quality. Zdraw Vestn. 2013;82:298-307.
Tsunoda S, Kawano N, Miyado K, Kimura N, Fujii J. Impaired fertilizing ability of superoxide dismutase 1-deficient mouse sperm during in vitro fertilization. Biol Reprod.2012;87:121. PMID: 22933517 DOI: 10.1095/biolreprod.112.102129

Varshini J, Srinag BS, Kalthur G, Krishnamurthy H, Kumar $P$, Rao SBS, Adiga SK. Poor sperm quality and advancing age are associated with increased sperm DNA damage in infertile men. Andrologia. 2011;44:642-9. PMID: 22040161 DOI: 10.1111/j.1439-0272.2011.01243.x

Velez de la Calle JF, Muller A, Walschaerts M, Clavere JL, Jimenez C, Wittemer $C$, Thonneau P. Sperm deoxyribonucleic acid fragmentation as assessed by the sperm chromatin dispersion test in assisted reproductive technology programs: results of a large prospective multicenter study. Fertil Steril. 2008;90:1792-9. PMID: 18166175 DOI: 10.1016/j.fertnstert.2007.09.021

Wang C, Swerdloff RS. Limitations of semen analysis as a test of male fertility and anticipated needs from newer tests. Fertil Steril. 2014;102:1502-7. PMID: 25458617 DOI: $10.1016 /$ j.fertnstert.2014.10.021

Winkle T, Rosenbusch B, Gagsteiger F, Paiss T, Zoller N. The correlation between male age, sperm quality and sperm DNA fragmentation in 320 men attending a fertility center. J Assist Reprod Genet. 2009;26:41-6. PMID: 19030983 DOI: $10.1007 / \mathrm{s} 10815-008-9277-3$

Wiweko B, Utami P. Predictive value of sperm deoxyribonucleic acid (DNA) fragmentation index in male infertility. Basic Clin Androl. 2017;27:1. PMID: 28239474 DOI: $10.1186 / \mathrm{s} 12610-016-0046-3$

World Health Organization (WHO). WHO laboratory manual for the examination and processing of human semen. 5th ed. Geneva: WHO; 2010. PMID: 21243747

Zhang LH, Qiu Y, Wang KH, Wang Q, Tao G, Wang LG. Measurement of sperm DNA fragmentation using brightfield microscopy: comparison between sperm chromatin dispersion test and terminal uridine nick-end labeling assay. Fertil Steril. 2010;94:1027-32. PMID: 19505686 DOI: $10.1016 /$ j.fertnstert.2009.04.034 